\title{
Effects of Increasing Exchange Rate on the Export Performance in Sri Lanka: A Gravity Model Approach
}

\author{
Uthpala Jaysinghe $^{1}$ and Renée Fry-McKibbin ${ }^{2}$
}

\begin{abstract}
This paper attempts to identify the causal relationship between rising of real effective exchange rate and the export performance in Sri Lanka for the period of 2000 to 2016. Study employed a Gravity model approach using a panel data set of 174 trading partner countries. The study finds that there is no significant impact of rising of exchange rate on export performance during the period of study. It is also found that GDP, distance, FDI, country being landlocked, global financial crisis and ending of civil war have a significant impact on export performance of the country.
\end{abstract}

Keywords: Real effective exchange rate, Export performance, Gravity model, Sri Lanka

\footnotetext{
${ }^{1}$ Hector Kobbekaduwa Agrarian Research and Training Institute, Colombo, Sri Lanka.

${ }^{2}$ Crawford School of Public Policy, Australian National University, Australia.
} 


\section{Introduction}

Over the past few decades Sri Lankan exchange rate has changed enormously. According to the theory, in general when the exchange rate increases or when the domestic currency depreciates it stimulates exports as export prices increase. On the other hand, it discourages imports as import prices increase. Exchange rate can be either fixed or floating. Under floating exchange, market forces determine the currency rates. Fixed exchange rates imply that fixing or pegging domestic currency in to a generally accepted currency such as US dollar. The objective of fixing the exchange rate is to reduced volatility of the local currency which will result in less turbulences in the domestic currency. Exchange rates and export performance of a country has a close relationship. Sri Lankan exchange rate policy changes time to time over the decades while current exchange rate policy is floating exchange rate. As shown in the Figure 1 the exchange rate in Sri Lanka has increased overtime while the domestic rupee value is depreciating. However, it is a question whether this increase in exchange rate has contributed to increase in export volume of the country.

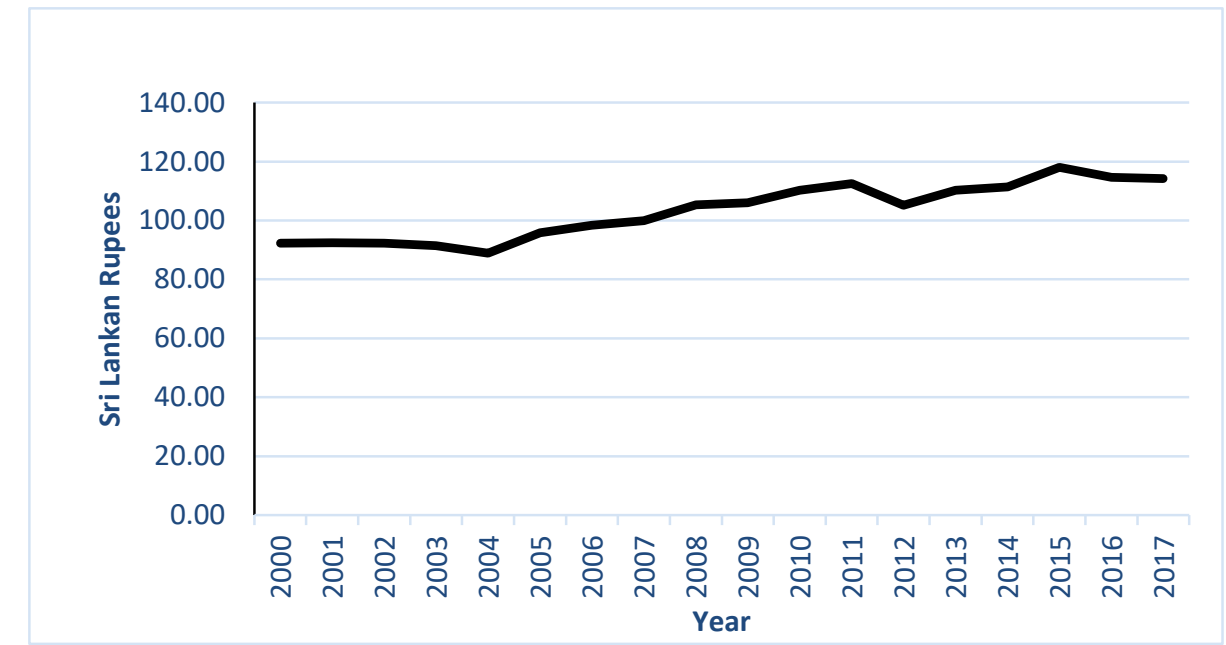

Figure 1: Real effective exchange rate in Sri Lanka during the period of 2000-2017

Source: Bruegel.org 


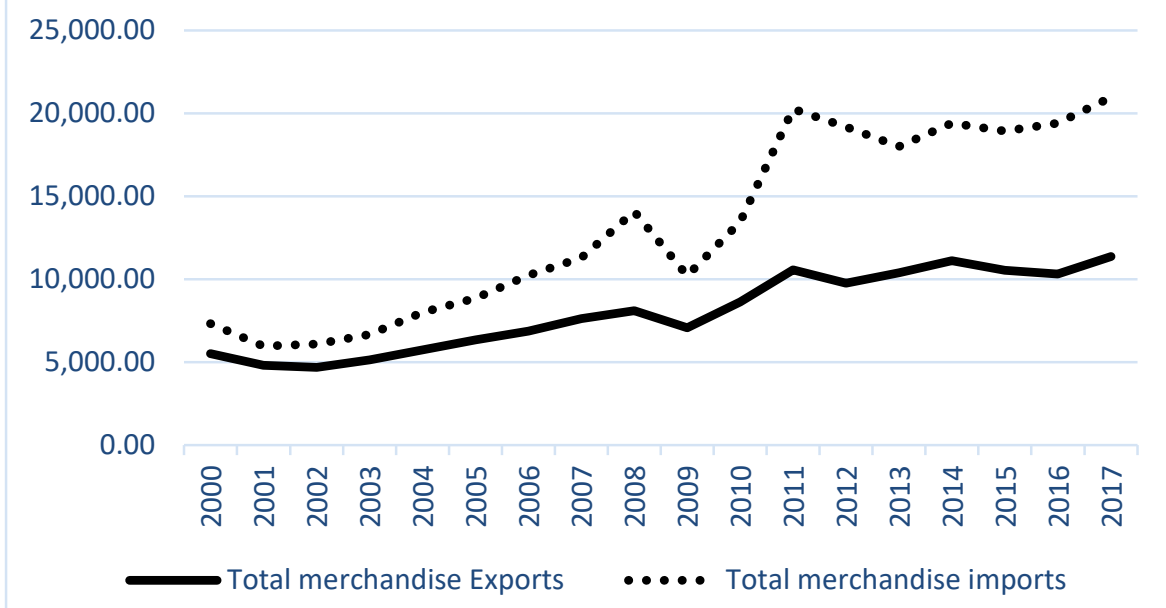

Figure 2: Total merchandize exports and imports in Sri Lanka (USD million) for the period of 2000-2017

Source: World Integrated Trade Solutions (World Bank data)

The Figure 2 shows how the exports and imports have change over time for the period of year 2000 to 2017. The graph shows that the exports have increased over time however, the increase of imports is greater compared to exports, widening the trade deficit of the country. One of the key features for the development of a country is rise in the exports of the country.

Hence, it is important to identify the contribution of increase in exchange rate towards export performance of the country. Therefore, this study aims to identify the impact of increase in exchange rate on export performance of Sri Lanka using a Gravity Model while identifying other key determining factors influencing on export performance of the country.

The paper has divided in to five major sections. The first section provides a brief introduction to the study. The second section discusses previous studies carried out in the similar subject area and how the exchange rate policy has changed in Sri Lanka during the past few decades. The third section discusses the methodology adopted in this study and type of data used. Fourth section presents the findings of the study. The fifth section gives the concluding remarks for the study. 


\section{Empirical Evidence}

Since 1973 the exchange rate volatility of developed and developing countries has increased due to the adoption of a floating exchange rate policy resulting from US dollar devaluation (Choudhury, 2005). Literature suggests that the uncertainty induced by exchange rate volatility create ambiguity among business communities across borders which leads to poor trade performance, and impacts on the economic performance of a country (Hall et al., 2010). According to Hall et al (2010), the impact of changes in exchange rate policies on export performance show equivocal results. Considering industrialised countries, the relationship between the exchange rate policies and trade flows shows ambiguous nature as some studies shows that either there is no significant relationship or slightly negative or positive relationship. With regards to developing countries, many studies suggest that the high volatility levels have negatively impact on export performance (Arize et al., 2000).

A study conducted by Chowdhury (1993) for G 7 countries using multivariate error correction method found that high volatility has a significant negative impact on trade volume for $G 7$ countries. According to this study the main reason is that exporters are risk averse thus they have either reduced export volumes or change the commodity price or shift in to another business.

Cushman (1988) identified how bilateral trade flows affected by floating exchange rate policy in the USA. The findings gave mixed results where some flows show a significant negative impact while few gave significant positive impact. However, the majority gave significantly negative results.

According to literature there is a negative and significant relationship between volatility of exchange rate policies and export performance in developing countries (Bahmani-Oskooee, 2002; Doroodian, 1999; Rahmatsyah et al. 2002; Sauer \& Bohara, 2001).

Hayakawa and Kimura (2009) found that the magnitude of the negative impact of highly volatile exchange rate on trade in East Asian countries are higher than other regions of the world. Authors further state that one of the major reasons behind this is the higher sensitivity of exchange rate volatility for intermediate goods which accounts for major fraction of East Asian trade. 
Arize et al. (2000) identified the impact of exchange rate volatility for 13 less developed countries including Sri Lanka for the period of 1973 to 1996 and concluded that the relationship is negatively significant in both short and long run.

Particularly in Sri Lankan perspective Weliwita et al. (1999) identified the impact of exchange rate volatility of Sri Lanka considering its six trading partner countries under the floating exchange rate policy for the period of 1978 to 1996 . They found that the high volatility has significantly hindered the export performance in Sri Lanka.

Ekanayake and Chatna (2010) identify the impact of exchange rate volatility on Sri Lankan export performance using generalized ARCH-type model. The results showed blurred conclusions as the results were different for different product groups. However, with regards to majority of products, high volatility in exchange rate has obstructed the export performance as a result of higher uncertainty which leads risk averse exporters to reduce the export quantity.

Paudel and Burke (2015) found how changes in exchange rate policy regime in Nepal have impacted the export performance of the country for the period of 1980 to 2010 using the Gravity model. The results indicate that the appreciation of real exchange rate in Nepal has a significant negative impact on export performance.

Though literature is available to identify how the exchange rate volatility has impacted the export performance of various countries and regions there were hardly any literature to understand how change or rise in exchange rate has impacted the export performance in Sri Lanka. Hence, the study aims to identify whether increase in real effective exchange rate has an impact on export performance of Sri Lanka.

\section{The Trend of Exchange Rate Policies in Sri Lanka}

After the open market policies in 1977, Sri Lanka has adopted unified exchange rate to reflect foreign exchange market status over the duel exchange policy which was practicing up till then. However, the nominal exchange rate was used in 1981 to anchor to cover inflation. Afterwards the inflation rate of the country has been increased as the government started bigger public sector investment programmes. Therefore, the Central Bank of Sri Lanka (CBSL) adopted a tightly managed float policy which lead to appreciate the real exchange rate during the rest of the decade which reflected higher domestic inflation compared to Sri Lanka's main trading partners. In 1989 there was a 
sharp depreciation of rupee compared to the US Dollar. Thus the CBSL was adjusting the exchange rate daily while paying attention to the developments of the foreign exchange market and the real exchange rate. (Athukorala et al., 2017).

The government kept the budget deficit under control supported by ceasefire agreements with Liberation Tigers of Tamil Eelam along with increased flexibility in exchange rate management. This has allowed to avoid real exchange rate misalignment during early 1990s.

During the second half of 1990s, the cost of war increased resulting a negative impact on domestic macroeconomic status. Hence International Monetary Fund (IMF)) led floating exchange rate regime was introduced in 2001. Under floating exchange rate nominal exchange rate was adjusted and this was used to reverse mild appreciation of the real exchange rate during the latter part of 1990s. Thus in year 2002 real exchange rate could recoup in to the level it had been in early 1990s (Athukorala et al., 2017).

In the years of 2006-2008 CBSL could maintain stable nominal exchange rate by drawing foreign reserves and foreign borrowings. However, in year 2008 the country was in a balance of payments crisis. As a result, the country came in to a stand-by agreement with the IMF of US dollar 2.5 billion intending to avoid balance of payment crisis, improve investor assurance and stabilize the exchange rate. However, the country failed to keep the promises (Athukorala et al., 2017).

In the year 2012 with the widening current account deficit and drastically reducing foreign exchange reserves CBSL had to abandon foreign exchange market intervention to back up exchange rate. However, by 2013 the CBSL could again stabilize exchange rate by drawing on foreign exchange reserves built via sovereign bond issues. It is important to note that the stabilized exchange rate along with domestic inflation which was higher than trading countries have led to an appreciated real exchange rate by about $22 \%$ during the period of 2005-2014 compared to earlier 5 years. This has reduced the competitiveness of export oriented and import competing production. In the year 2015 CBSL permitted higher flexibility in determination of the exchange rate. In year 2016 CBSL was focusing on flexible exchange rate regime and inflation targeting (Athokorala et al., 2017). 


\section{Methodology}

\section{Model Specification}

The Gravity model was employed assess the impacts of exchange rate on export performance. According to Linnemann (1966) and Anderson (1979) this is the most successful empirical trade model which can be used to analyse bilateral trade flows. The model was firstly introduced to analyse trade flows by Tinbergen (1962) followed by the Anderson (1979), Deardorff (1980), and Bergstrand and Peter (2009) who contributed to modify the model later on. This model can be effectively used to analyse varying range of commodities moving over borders under different scenarios. The theory behind the model says the trade between two countries happen similar to the Newton's Law of Gravitation. Therefore, the goods and services trade between two countries is directly proportional to the economic mass of two countries or the GDP and inversely proportional to the geographical distance between two countries. The original model can be depicted as follows (Kalirajan, 2018).

$$
X_{i j}=C \frac{Y_{i t}}{t_{i j}}
$$

$X_{i j}=$ Bilateral trade between country $\mathrm{i}$ and $\mathrm{j}$

$\mathrm{C}=$ Constant

$\mathrm{Y}=$ Economic mass or the GDP

$\mathrm{T}=$ Trade cost between countries (geographical distance)

Gravity model can be applied to all three types of cross section, time series and panel data. Though the basic model is as above there are many other factors which have an impact on the trade between countries which can be broadly categorized as follows. Firstly, natural constraints such as geographical distance between two countries. Secondly behind the border constrains such as infrastructure and institutional conditions and constraints in the exporting country. Thirdly beyond the border constraints which primarily refers to the infrastructure and institutional conditions and constraints in the importing country (Kalirajan 2018).

Beyond the border constraints can be further categorised in to two as "implicit beyond border constrains" and "explicit beyond border constraints". The implicit beyond the border constraints mainly refers to institutional and infrastructure constraints in the importing country which is in general difficult to measure. Explicit beyond the border constraints mainly refers to the exchange rates and tariffs (Kalirajan, 2018). Supply and demand factors and trade agreements are the other major determinants of trade (Kalirajan, 2018). 
Taken in to consideration all above factors, the gravity model developed to analyse the impact of exchange rate on export performance of Sri Lanka is given as follows (Fry-McKibbin \& Nguyen, 2017; Kalirajan, 2018).

$$
\begin{aligned}
& \ln \left(Y_{j t}\right)=\beta_{0}+\beta_{1} \ln \left(\text { lreer }_{i t}\right)+\beta_{2} \ln \left(\text { population }_{i t}\right)+\beta_{3} \ln \left(\text { gdp }_{i t}\right)+ \\
& \beta_{4} \ln \left(\text { distance }_{i}\right)+\beta_{5} \ln \left(\text { tariff }_{t}\right)+\beta_{6} \ln \left(\text { fdi }_{t}\right)+\beta_{7}\left(\text { comcol }_{i}\right)+ \\
& \beta_{8}\left(\text { landlocked }_{i}\right)+\beta_{9}\left(\text { gspplus }_{i t}\right)+\beta_{10}\left(\text { indosri }_{i t}\right)+\beta_{11}\left(\text { pakisri }_{i t}\right)+ \\
& \beta_{12}\left(\text { APT }_{i t}\right)+\beta_{13}\left(\text { SAFT }_{i t}\right)+\beta_{14}\left(\text { SAPT }_{i t}\right)+\beta_{15}\left(\text { financialcri }_{t}\right) \\
& +\beta_{16}\left(\text { war }_{t}\right)+v_{i t}
\end{aligned}
$$

$\ln \left(Y_{j t}\right)$ is natural log value of annual real exports from Sri Lanka to trading partner country $\mathrm{i}$ in the year $\mathrm{t} . \ln \left(\right.$ lreer $\left._{i t}\right)$ is the natural $\log$ value of Real Effective Exchange Rate (REER) of the trading partner country i. $\ln \left(\right.$ population $\left._{i t}\right)$ is the natural $\log$ value of population of the country $i$ in the year t. $\ln \left(g d p_{i t}\right)$ is the natural log value of gdp of the trading partner country $i$ in the year $\operatorname{t} \ln \left(\operatorname{tarif} f_{t}\right)$ is the natural $\log$ value of the import tariff rate (weighted mean value for all products) for Sri Lanka for the year $t . \ln \left(f d i_{t}\right)$ depicts the natural log value of Foreign Direct Investment (FDI) for Sri Lanka for the year t. comcol $_{i}$ is a binary variable where 1 if the country $i$ is having a common coloniser and 0 other wise. landlocked $d_{i}$ is again a binary variable where 1 if the country $\mathrm{i}$ is land locked and 0 otherwise. gspplus $i t$ is another binary variable where 1 if the country $i$ is having GSP plus trade facility with Sri Lanka in the year $\mathrm{t}$ and 0 otherwise. indosrit $_{i t}$ is also a binary variable where 1 if the country is India in the year $t$ after the Indo Sri Lanka Free Trade Agreement and 0 other wise. pakisrit it is another binary variable where if the country $i$ is Pakistan after year $t$ where the Pakistan Sri Lanka Free Trade Agreement was signed. APT $A_{i t}$ is a binary variable where 1 if the country $i$ has signed Asia- Pacific Trade Agreement after year $\mathrm{t}$ and 0 other wise. SAFT $A_{i t}$ is a binary variable where 1 if the country $i$ has signed South Asian Free Trade Agreement after year $t$ and 0 other wise. $S A P T A_{i t}$ is a binary variable where 1 if the country i has signed South Asian Preferential Trade Agreement after year $t$ and 0 other wise. financialcri $i_{t}$ is another binary variable where 1 if during the period or after global financial crisis and 0 otherwise. war $_{t}$ is the final binary variable where 1 is the year $\mathrm{t}$ is after the civil war in Sri Lanka and 0 otherwise.

Since literature suggested that volatility of exchange rate is an important variable to determine exports, I have tried to incorporate exchange rate volatility variable in to gravity model by generating a 
variable to measure exchange rate volatility using a type of $\mathrm{ARCH}$ model (Autoregressive Conditional Heteroscedastic Model) specifically focusing on GARCH model (Generalized Autoregressive Conditional Heteroscedastic Model). However, due to limited time availability that effort was not successful (Ekanayake \& Chatrna, 2010).

To estimate the model STATA 14 was used. $v_{i t}=u_{i}+e_{i t}$ is the error term of the model and unobserved effects $u_{i}$ are not correlated with the explanatory variables during all times. Considering the model specification, over both fixed effects model and pooled ordinary least squares model, random effects model was selected. Since the effects of being land locked and the distance cannot be separated from the Real Exchange Rate variable the fixed effects model was not considered in this study. However, Breush and Pagan Lagrange multiplier test statistics for the random effects model which is 4861.12 with the probability value of 0.0000 proves the selection of the random effects model over pooled ordinary least squares model (Fry-McKibbin \& Nguyen 2017).

\section{Data}

For the analysis, panel data were collected for the period from 2000 to 2016 from 174 partner countries. The data, data sources and the expected sign of the results are as follows;

Real exports data were collected from World Integrated trade solutions. This is the dependent variable of the model. Due to limited data availability the study only considered merchandise exports from Sri Lanka to partner countries. Therefore, services exports are not included in to the model.

REER data which is the main variable of interest were collected from Brugel.org. REER indicates the relative profitability of exporting rather than selling in the domestic market. It is expected to have a positive relationship as when REER increases domestic currency depreciates and profitability of exporting increases. Hence the expected sign is positive.

GDP data were collected from World Development Indicators (World Bank data). If the economies are larger, there will be greater trade flows between countries. Therefore, the expected sign is positive.

Distance data were collected from CEPII database. When the geographical distance is increasing, the economic cost between 
countries increase which leads to lesser trade flows between countries. Hence the expected sign is negative.

Tariff data were collected from World Development indicators (World Bank Data). According to Lerner (1936) whether it is export taxes or import tariffs perform the same task. Import tariffs also reduces the profitability of exporting commodity. Therefore, the expected relationship is negative.

FDI data were collected from United Nations Conference on Trade and Development. Since FDI promotes investments in industries the expected sign of FDI on exports is positive (Zhang, 2005).

Common Colonizer data were collected from CEPII data set. When the country is having a common coloniser it is expected to have previously established relationships which is favourable for trade. Thus the expected sign is positive.

Land locked data were gathered from CEPII database. When the country is land locked the transportation cost increases which leads to increase in export commodity prices (Paudel \& Burke, 2015). Therefore the expected sign is negative.

The data on trade agreements (GSP plus, India Sri Lanka Free Trade Agreement, Pakistan Sri Lanka Free trade Agreement, APTA, SAFTA and SAPTA) were collected from the Central Bank of Sri Lanka (2017). Since the trade agreements expected to facilitate trade the expected sign for all the trade agreements are positive.

GSP plus trade agreements was given to Sri Lanka for the commodities that are exporting in to European Union (EU) countries, USA, Australia, Japan, Canada, Russia and Turkey. This facility was commenced in the year 2005 and suspended for Sri Lanka in year 2010 due to human rights violation issues against Sri Lanka during the post war period. India Sri Lanka Free trade Agreement was signed with effect from the year 2000. APTA was sign with effect form 2006 and the countries included are China, Bangladesh, India, Lao, Republic of Korea and Sri Lanka. Pakistan Sri Lanka free trade agreement was signed with effect from 2005. SAFTA was signed with effect from 2006 and the included countries are Afghanistan, Bangladesh, Bhutan, India, Maldives, Nepal, Pakistan and Sri Lanka. SAPTA was signed with effect from 1995 and the countries under the agreement are Bangladesh, Bhutan, India, Maldives, Nepal, Pakistan and Sri Lanka. 
The global financial crisis was firstly happened in the year 2007 and continued till 2008. According to Milanovic (2016) though the global financial crisis negatively impacted most of the western developed countries the impact was positive to most of the Asian nations and therefore, world economic crisis likely to have a positive impact on export performance.

The civil war in Sri Lanka ended in the year 2009. When the countries are stable, investments on the development of the country will be increased which is favourable for exports. Therefore, the expected sign is positive.

\section{Results and Discussion}

Table 1 shows the correlation matrix for the variables. The correlation between real exports and REER is negative which is opposite to the expected sign and was the variable of interest in this study. Other control variables such as tariff rates and common colonizer variables show an opposite correlation than expected correlation as well. 
Table 1: Correlation matrix

\begin{tabular}{|c|c|c|c|c|c|c|c|}
\hline Independent variable & $\begin{array}{l}\ln \text { Real } \\
\text { Exports }\end{array}$ & ln REER & In Population & $\ln$ GDP & ln Distance & ln Tariff & $\ln$ FDI \\
\hline In Real Exports & 1.0000 & & & & & & \\
\hline ln REER & -0.0245 & 1.0000 & & & & & \\
\hline In Population & 0.5921 & -0.0187 & 1.0000 & & & & \\
\hline $\ln$ GDP & 0.8046 & -0.0233 & 0.7275 & 1.0000 & & & \\
\hline ln Distance & -0.2428 & -0.0474 & -0.2201 & -0.0870 & 1.0000 & & \\
\hline $\ln$ Tariff & 0.0028 & -0.1564 & -0.0094 & -0.0256 & 0.0026 & 1.0000 & \\
\hline $\ln$ FDI & 0.0207 & 0.1557 & 0.0262 & 0.1583 & -0.0064 & -0.6666 & 1.000 \\
\hline Common Colonizer & -0.1577 & 0.0706 & -0.3727 & -0.3112 & -0.1464 & 0.0031 & -0.0042 \\
\hline Landlocked & -0.2421 & 0.0079 & 0.0092 & -0.1662 & -0.1617 & -0.0085 & 0.0167 \\
\hline GSP plus & 0.2431 & -0.0439 & 0.0778 & 0.3100 & 0.0453 & 0.2514 & 0.0580 \\
\hline Indo Sri Lanka & 0.1440 & -0.0110 & 0.2108 & 0.1233 & -0.2251 & 0.0008 & -0.0015 \\
\hline Pakistan Sri Lanka & 0.0751 & 0.0007 & 0.1096 & 0.0511 & -0.1199 & 0.0074 & 0.0345 \\
\hline APTA & 0.1034 & 0.0373 & 0.2314 & 0.1660 & -0.2173 & -0.0113 & 0.0910 \\
\hline SAFA & 0.0797 & 0.0457 & 0.1253 & 0.0145 & -0.3769 & -0.0184 & 0.1042 \\
\hline SAPTA & 0.1250 & 0.0176 & 0.1456 & 0.0079 & -0.4648 & -0.0035 & -0.0002 \\
\hline Global financial crisis & 0.0149 & -0.0066 & 0.0028 & 0.0358 & 0.0038 & 0.3518 & 0.2726 \\
\hline End of civil war & 0.0068 & 0.1983 & 0.0227 & 0.1191 & -0.0062 & -0.6098 & 0.6465 \\
\hline
\end{tabular}


The table 2 shows the parameter estimates for the natural log value for total exports and total real exports. The coefficient value for REER shows that there is no significant relationship between REER and the export volume of Sri Lanka. However, according to general theory when the exchange rate is increasing or when the local currency is depreciating the export volume should increase as the value of the exporting goods will rise. Hence, countries such as China tend to under value local currency or keep the local currency value over the market equilibrium to promote exports.

Despite the theory, according to literature the relationship between exchange rate and export performance is mixed and the results depends on several factors such as the measure of exchange rate volatility and nature of trade flows. For an example while Aye et al (2015) states exchange rate uncertainty has a negative significant effect on exports Franke (1991) says in Germany exporting firms benefit from high exchange rate volatility. A study done in Turkey says exports are not sensitive to the changes in exchange rates. Fountas and Aristotelous (2005) and Ekanayake and Chatrna (2010) states that the export volume highly depends on the exchange rate regime. When a fixed exchange rate policy is adopted since there will be low risk for exchange rate to fluctuate, risk averse exporters will start exporting more where as if floating or flexible exchange rate is adopted they will invest less on exports. According to recent literature high volatility rates in exchange rate reduces total export performance of Sri Lanka Ekanayake and Chatrna, 2010. This is in line with the findings of Choudhry (2005) and Chou (2000).

Another possible reason for this finding is related to the structure of industrial production process, such as raw material, intermediate good and technology sources. If exporting firms heavily depend on imported materials and technology, the expected benefit of increasing export volume will be reduced and therefore the impact of the increasing of exchange rate on export can be either neutral or negative. This happens as when the local currency depreciates due to the increasing of exchange rate, the value of imported goods technologies become expensive which can hinder the advantage for exports.

As expected, GDP has a positive significant relationship with the export volume. When GDP increase by one percent real exports will increase by 0.8354664 percent.

The distance between partner country and Sri Lanka also has a negative significant relationship as expected. When the distance 
between Sri Lanka and the partner country increased by one percent real exports will reduce by 0.9303798 percent.

However, FDI and export performance has a negative significant relationship which has not been expected. The common acceptance is that FDI promotes export growth by several means such as accumulating capital to support export growth, promoting export growth via inflow of new products and technology, opening up more avenues to explore foreign markets, enhancements of export performance via inflow of new skills and knowledge which helps in human resource development. However, according to Zhang (2005) FDI not necessarily support to increase export performance due to several other reasons. Firstly, FDI will not make a significant contribution in increasing exports when the domestic savings and investments are low and FDI might be targeting development of domestic markets rather than developing export oriented industries. FDI can also hinder local firms who have the ability to become exporters. Thus these factors might have influenced to get negative relationship between FDI and export performance.

As expected, countries being landlocked has a negative significant relationship with export performance. When the trading partner country is land locked the real exports will decrease by 1.227949 percent compared to a country who has the access to a sea port.

It is interesting to notice that trade agreements do not show a significant impact on export performance at the global level. However, as shown in the Table 3, when the gravity model is run for countries after classifying them in to different regions, the relationship between trade agreements and the export are mostly negative.

On the other hand aim of trade agreements are to increase trade volume either export or import. Therefore, it is not always the case that it can automatically increase export. It depends on the clause in each bilateral trade agreements and the capabilities of both government and domestic exporting firms in exploiting all chances provided in the agreements for increasing export volumes. There are still some potential problems in implementing trade agreement between countries, such as national security, national interest and domestic standard for good and services. So, if government and firms cannot maximize all possible benefits of the agreement then it will not be a surprise that it cannot increase exports.

The model shows that the global financial crisis, has a negative significant relationship with the export performance which is opposite 
to what we have expected. According to Milanovic (2016), though the global financial crisis has negatively impacted the developed countries, its' impacts on Asian countries can be positive. However, in the case of Sri Lanka, the USA and EU are the leading export markets for textile and wearing apparel which are the major exports of country. Therefore, the country's exports largely depend on the demand from these developed countries. Perhaps, the most depressing reality of Sri Lankan export performance is that developed countries invest in labour intensive industries of Sri Lanka to gain a comparative advantage from the use of abundant labour, making the country's labour force vulnerable to global economic shocks. The model results clearly indicate this effect. 
Table 2: Parameter estimates of the gravity model for natural log value of total exports and total real exports

\begin{tabular}{|c|c|c|}
\hline Independent variable & ln Total exports & In Total real exports \\
\hline \multirow[t]{2}{*}{ ln REER } & -.3144103 & -.2713523 \\
\hline & $(.2504439)$ & $(.2534562)$ \\
\hline \multirow[t]{2}{*}{ In Population } & 0.0598438 & .1139777 \\
\hline & $(.2504439)$ & $(.0948679)$ \\
\hline \multirow[t]{2}{*}{$\ln$ GDP } & $.9451116 * * *$ & $.8354664 * * *$ \\
\hline & $(.0696892)$ & $(.0680259)$ \\
\hline \multirow[t]{2}{*}{ ln Distance } & $-.9254195 * * *$ & $.9303798 * * *$ \\
\hline & $(.2142697)$ & $(.2123119)$ \\
\hline \multirow[t]{2}{*}{$\ln$ Tariff } & $-.7210056 * * *$ & -.3249834 \\
\hline & $(.340001)$ & $(.2814164)$ \\
\hline \multirow[t]{2}{*}{$\ln$ FDI } & $.1370922 *$ & $.216182 * * *$ \\
\hline & $(.0759745)$ & $(.0604251)$ \\
\hline \multirow[t]{2}{*}{ Common colonizer } & .2390093 & .1634442 \\
\hline & $(.2606813)$ & $(.2536998)$ \\
\hline \multirow[t]{2}{*}{ Landlocked } & $-1.275785 * * *$ & $1.227949 * * *$ \\
\hline & $(.3233217)$ & $(.2938432)$ \\
\hline \multirow[t]{2}{*}{$\mathrm{GSP}+$} & .0178726 & -.0176124 \\
\hline & $(.0624771)$ & $(.0728745)$ \\
\hline \multirow[t]{2}{*}{ Indo Sri Lanka } & -.531799 & .4397641 \\
\hline & $(.8316146)$ & $(.7894575)$ \\
\hline \multirow[t]{2}{*}{ Pakistan Sri Lanka } & -.0597508 & -.103451 \\
\hline & $(.3019546)$ & $(.3079422)$ \\
\hline \multirow[t]{2}{*}{ APTA } & -.3724168 & -.2666997 \\
\hline & $(.5944606)$ & $(.5031165)$ \\
\hline \multirow[t]{2}{*}{ SAFTA } & -.2660269 & -.2895281 \\
\hline & $(.3852213)$ & $(.3890338)$ \\
\hline \multirow[t]{2}{*}{ SAPTA } & .6105135 & 6002867 \\
\hline & (.9716097) & $(.9322271)$ \\
\hline \multirow[t]{2}{*}{ Global financial crisis } & $.003724 *$ & $.0212165^{* * *}$ \\
\hline & $(.0625723)$ & $(.0518074)$ \\
\hline \multirow[t]{2}{*}{ Sri Lankan war } & $.1658042 *$ & $.1749633 * * *$ \\
\hline & $(.0876922)$ & $(.0702019)$ \\
\hline R square & 0.6998 & 0.7067 \\
\hline Number of observations & 2,250 & 2,237 \\
\hline Number of importers & 174 & 174 \\
\hline
\end{tabular}

Note: Standard errors are shown in the brackets.

Significance levels of probability values are shown follows $(\mathrm{p}<0.01)^{* * *},(\mathrm{p}<0.05)^{* *},(\mathrm{p}<0.1)^{*}$ 
Ending of Sri Lankan civil war also does not give expected results. In general, when the country is peaceful and stable it will attract more investors. Allocation of investment on civil war now can be re allocated to invest country's development. These factors will promote the growth of the country and export performance. However, according to the model results, ending of war has a negative significant impact on exports. The major probable reason is that Sri Lanka faced lots of war crimes and human rights violation allegations which has resulted in imposing trade barriers against Sri Lanka during the post war period. Especially the GSP plus facility which was one of the biggest trade advantage for Sri Lanka was suspended since 2010 till 2018 as a result of this. Hence it has negatively impacted on exports rather than positive effects as expected with zero civil war scenario.

Table 3 shows the results for countries which has categorized in to seven major geographical regions of the world. In the East Asia and Pacific (EAP) region GDP shows a positive significant relationship and FDI shows a negative significant relationship. However, one of the key points is that the GSP plus facility shows a negative significant relationship. The GSP plus facility was given to selected developing or lower middle income countries and Sri Lanka has taken this advantage to export, especially textiles, to developed countries. Australia and Japan are the only countries which apply GSP plus facility in East Asia and Pacific region. The negative relationship was observed because since GSP plus facility gives more profits to exporters and they focus on exporting more to developed countries especially in the west than exporting to other countries.

The second category is Europe and central Asia (ECA). In this category the variables of population, GDP and having a common colonizer shows a positive significant relationship for exports which is inline with the expected sign.

The third category is Latin America and the Caribbean (LAC). The results for population and GDP shows a positive significant relationship with exports which is inline with the expected sign. However, it is important to observe that the distance shows a positive significant relationship with exports which is totally opposite to the expected sign. 
Table 3: Parameter estimates of gravity model for total real exports for different regions of the world. Standard errors are shown in the brackets

\begin{tabular}{|c|c|c|c|c|c|}
\hline $\begin{array}{l}\text { Independent } \\
\text { variable }\end{array}$ & EAP & ECA & LAC & MENA & $\mathrm{NA}$ \\
\hline ln REER & $\begin{array}{l}0.974274 \\
(0.7774981)\end{array}$ & $\begin{array}{l}0.7933669 \\
(0.7732935)\end{array}$ & $\begin{array}{l}0.2587574 \\
(0.3014828)\end{array}$ & $\begin{array}{l}0.3168064 \\
(0.3696245)\end{array}$ & $\begin{array}{l}2.889653 * * \\
(1.280244)\end{array}$ \\
\hline In Population & $\begin{array}{l}-0.1854445 \\
(0.3717322)\end{array}$ & $\begin{array}{l}.6487284 * * * \\
(0.204919)\end{array}$ & $\begin{array}{l}.4467402 * \\
(0.2579561)\end{array}$ & $\begin{array}{l}0.1715108 \\
(0.2458694)\end{array}$ & $\begin{array}{l}3.737842 * * * \\
(1.114968)\end{array}$ \\
\hline ln GDP & $\begin{array}{l}1.181677 * * * \\
(0.1871501)\end{array}$ & $\begin{array}{l}.6318648 * * * \\
(0.1551099)\end{array}$ & $\begin{array}{l}.4674624 * * \\
(0.1847047)\end{array}$ & $\begin{array}{l}.6147064 * * * \\
(0.1969427)\end{array}$ & $\begin{array}{l}-2.285272 * * \\
(1.105519)\end{array}$ \\
\hline In Distance & $\begin{array}{l}-0.5495358 \\
(0.7561037)\end{array}$ & $\begin{array}{l}0.8039492 \\
(0.9968383)\end{array}$ & $\begin{array}{l}5.030691 * * * \\
(1.921565)\end{array}$ & $\begin{array}{l}-1.364604 \\
(0.9909965)\end{array}$ & $\begin{array}{l}-.90074 * * * \\
(0.257377)\end{array}$ \\
\hline $\ln$ Tariff & $\begin{array}{l}1.027289 \\
(0.6804541)\end{array}$ & $\begin{array}{l}0.038117 \\
(0.507753)\end{array}$ & $\begin{array}{l}-0.2298417 \\
(0.5597958)\end{array}$ & $\begin{array}{l}0.7219397 \\
(0.532348)\end{array}$ & $\begin{array}{l}0.3290602 \\
(0.9919608)\end{array}$ \\
\hline $\ln \mathrm{FDI}$ & $\begin{array}{l}-.3583751 * * * \\
(0.1383425)\end{array}$ & $\begin{array}{l}-0.1734869 \\
(0.1075278)\end{array}$ & $\begin{array}{l}-0.1415295 \\
(0.1328698)\end{array}$ & $\begin{array}{l}-.3915623 * * * \\
(0.1053684)\end{array}$ & $\begin{array}{l}0.1712768 \\
(0.151353)\end{array}$ \\
\hline Com col & $\begin{array}{l}0.1923787 \\
(0.7481437)\end{array}$ & $\begin{array}{l}1.398195 * * * \\
(0.390922)\end{array}$ & $\begin{array}{l}0.4547299 \\
(0.7391486)\end{array}$ & $\begin{array}{l}0.2509671 \\
(0.7969927)\end{array}$ & \\
\hline Landlocked & $\begin{array}{l}-0.5022165 \\
(1.074842)\end{array}$ & $\begin{array}{l}-0.1885648 \\
(0.3638533)\end{array}$ & $\begin{array}{l}-0.2977144 \\
(0.8120611)\end{array}$ & & \\
\hline $\mathrm{GSP}+$ & $\begin{array}{l}-0.4244482 \\
(0.1259839)\end{array}$ & $\begin{array}{l}-0.1029532 \\
(0.0991836)\end{array}$ & & $\begin{array}{l}-0.1332204 \\
(0.0899594)\end{array}$ & $\begin{array}{c}-.210797 * * * \\
(0.0688337)\end{array}$ \\
\hline $\begin{array}{l}\text { ISLFTA } \\
\text { PSLFTA }\end{array}$ & & & & & \\
\hline
\end{tabular}




\begin{tabular}{|c|c|c|c|c|c|}
\hline $\begin{array}{l}\text { Independent } \\
\text { variable }\end{array}$ & EAP & ECA & LAC & MENA & NA \\
\hline APTA & $\begin{array}{l}-0.7291759 \\
(0.6579853)\end{array}$ & & & & \\
\hline $\begin{array}{l}\text { SAFTA } \\
\text { SAPTA }\end{array}$ & & & & & \\
\hline GFC & $\begin{array}{l}0.0670588 \\
(0.1087759)\end{array}$ & $\begin{array}{l}0.0988876 \\
(0.0812882)\end{array}$ & $\begin{array}{l}-0.0439274 \\
(0.1415065)\end{array}$ & $\begin{array}{l}0.0432776 \\
(0.06869)\end{array}$ & $\begin{array}{l}.1104779 * * * \\
(0.0261312)\end{array}$ \\
\hline SL civil war & $\begin{array}{l}-.247594 * \\
(0.138239)\end{array}$ & $\begin{array}{l}-0.1081625 \\
(0.086416)\end{array}$ & $\begin{array}{l}-0.143367 \\
(0.2027325)\end{array}$ & $\begin{array}{c}-0.0747874 \\
(0.122266)\end{array}$ & $\begin{array}{l}-0.038393 \\
(0.1119225)\end{array}$ \\
\hline $\mathrm{R}$ square & 0.8381 & 0.7475 & 0.7269 & 0.5306 & 0.9906 \\
\hline $\begin{array}{l}\text { No of } \\
\text { observations }\end{array}$ & 284 & 642 & 413 & 270 & 28 \\
\hline No of IMS & 22 & 47 & 31 & 20 & 2 \\
\hline
\end{tabular}


Table 3 (continuation) Parameter estimates of gravity model for total real exports for different regions of the world. Standard errors are shown in the brackets

\begin{tabular}{|c|c|c|}
\hline Independent variable & South Asia & Sub Saharan Africa \\
\hline \multirow[t]{2}{*}{$\ln$ REER } & -2.70407 & $-.917636 * *$ \\
\hline & (2.459384) & $(0.4399121)$ \\
\hline \multirow[t]{2}{*}{ ln Population } & -0.0074696 & 0.3033162 \\
\hline & $(0.7885433)$ & $(0.2190801)$ \\
\hline \multirow[t]{2}{*}{$\ln$ GDP } & 1.40653 & 0.3423976 \\
\hline & (1.303639) & $(0.2190801)$ \\
\hline \multirow[t]{2}{*}{ ln Distance } & $-6.667288 * * *$ & -0.3085776 \\
\hline & $(1.01693)$ & $(0.6569497)$ \\
\hline \multirow[t]{2}{*}{ ln Tariff } & -0.7306832 & $-1.877482 * * *$ \\
\hline & (2.016292) & $(0.7128166)$ \\
\hline \multirow[t]{2}{*}{$\ln$ FDI } & -0.1029578 & 0.2130236 \\
\hline & $(0.4203844)$ & $(0.1925899)$ \\
\hline \multirow[t]{2}{*}{ Common colonizer } & 0.7121925 & $1.001794 * *$ \\
\hline & $(1.352717)$ & $(0.4089198)$ \\
\hline \multirow[t]{2}{*}{ Landlocked } & & $-1.638731 * * *$ \\
\hline & & $(0.3797226)$ \\
\hline \multicolumn{3}{|l|}{$\mathrm{GSP}+$} \\
\hline ISLFTA & $\begin{array}{l}-3.974478 * * \\
(1.993738)\end{array}$ & \\
\hline \multirow[t]{2}{*}{ PSLFTA } & 1.127161 & \\
\hline & $(1.035972)$ & \\
\hline \multirow[t]{2}{*}{ APTA } & 0.2682383 & \\
\hline & $(0.4649136)$ & \\
\hline \multirow[t]{2}{*}{ SAFTA } & -0.6378942 & \\
\hline & $(0.4547853)$ & \\
\hline \multirow[t]{2}{*}{ SAPTA } & $-2.899264 * * *$ & \\
\hline & $(0.6154988)$ & \\
\hline \multirow[t]{2}{*}{ Global financial crisis } & -0.5892617 & -0.1146287 \\
\hline & $(0.4624909)$ & $(0.1430069)$ \\
\hline \multirow[t]{2}{*}{ Sri Lankan war } & $-.7935079 * * *$ & -0.0314949 \\
\hline & $(0.2502403)$ & $(0.2047279)$ \\
\hline R square & 0.9228 & 0.3421 \\
\hline Number of observations & 88 & 512 \\
\hline Number of importers & 7 & 45 \\
\hline
\end{tabular}

Note: Significance levels of probability values are shown follows $(\mathrm{p}<0.01)^{* * *},(\mathrm{p}<0.05)^{* *},(\mathrm{p}<0.1)^{*}$

The fourth category is Middle East and North Africa (MENA). This regions' GDP also shows a positive significant relationship while FDI shows a negative significant relationship. 
The fifth category is North America (NA). Only two countries (the United States of America and Canada) belong to this category. Most of the variables become significant for this region. One of the key factors is that the sample size is very small since only two countries are there in this category.

As shown in the Table 3 (continuation) the sixth category is South Asia. According to the results, distance shows a significant negative relationship in this region. One of the key observations is that the Indo Sri Lanka free trade agreement (ISLFTA) and SAPTA free trade agreement shows a significant negative impact on exports which was not expected. According to the study by Perera (2008) and Mukherji (2000), ISLFTA has helped achieve welfare gain for both countries. However, the free trade agreement has enhanced cheaper imports from India to Sri Lanka which has led to deteriorate the trade balance heavily.

The final category is Sub Saharan Africa (SSA). According to the results REER, tariff rates and partner country being landlocked show a negative significant impact on export performance of Sri Lanka.

\section{Conclusions}

In conclusion this study tried to understand the impact of increasing exchange rate on export performance in Sri Lanka. Results show that there is no significant relationship between rising exchange rate and export performance in Sri Lanka. This scenario can be explained using two probable factors. The first one is increased volatility of exchange rate under the floating exchange rate regime has hindered the advantage of having increasing exchange rate. The second one is increased exchange rates increase the value of imported goods and also the prices of imported raw materials. This might have removed the advantage of higher prices for exports.

The other major factors that has an influence on export performance are GDP, distance, FDI, country being landlocked, global financial crisis and ending of civil war of Sri Lanka. While GDP distance and country being landlocked gave the expected results FDI, global financial crisis and ending of civil war in Sri Lanka gave negative significant results which are opposite to the expected outcome.

FDI is expected to have a positive impact on exports however it depends on the economic situation of the country and in which industries the FDI is used on. Global financial crisis expected to have a positive significant impact on trade as post global financial crisis period was 
beneficial for Asian countries. However, the negative impact might be due to the fact that Sri Lanka exports mainly with developed countries. End of civil war also expected to have positive significant impact on trade whilst the results shows negative effects. The probable causes would be the post war allegations has been imposed trade barriers against Sri Lanka which has hindered the expected benefits from ending the war on export promotion.

Finally, it is interesting to see that none of the trade agreements showed a significant impact on export performance on global scale. However, when the countries are categorised based on geographical locations, there was a negative significant relationship between trade agreements and export performance. This implies that the benefits of Sri Lanka's trade negotiations and commitments are ambiguous.

\section{Acknowledgement}

I thank Professor Renée Fry-McKibbin (Australian National University) for Supervising the research work, I thank Thuong Nguyen (Australian National University) for supporting conducting the research, I thank Dr Subashini Perera (University of New England) for reviewing the manuscript and I thank Abdul Nasir (Australian National University) for reviewing the manuscript.

\section{References}

Anderson, J.E (1979). "A Theoretical Foundation for the Gravity Equation”, American Economic Review, vol. 69, pp. 106-116.

Arize, A.C., Osang, T and Slottje, D.J. (2000). Exchange Rate Volatility and Foreign Trade: Evidence from Thirteen LDC's. Journal of Business \& Economic Statistics, vol. 18, no. 1, pp.10-17.

Athukorala, P.C., Ginting, E., Hill, H. and Kumar, U. eds, 2017. The Sri Lankan economy: charting A new course. Asian Development Bank.

Aye, G.C., Gupta, R., Moyo, P.S., and Pillay, N. (2015). The Impact of Exchange Rate Uncertainty on Exports in South Africa. Journal of International Commerce, Economics and Policy, vol. 6, no1, pp. 1550004.

Bahmani-Oskooee, M. (2002). Does Black Market Exchange Rate Volatility Deter the Trade Flows? Iranian Experience. Applied Economics, vol. 34, no.18, pp. 2249-2255. 
Bergrstrand, J.H. and Peter, E. (2009). Gravity Equations and Economic Frictions in the World economy, in D Bernhofen, R Falvey, D Greenaway \& U Krieckemeier (eds), Palgrave Handbook of International Trade, Palgrave Macmillan Press.

Central Bank of Sri Lanka (2017). Central Bank Annual Report, Central Bank of Sri Lanka.

Chou, W.L. (2000). Exchange Rate Variability and China's Exports. Journal of Comparative Economics, vol. 28, no. 1, pp. 61-79.

Choudhury, T (2005). Exchange Rate Volatility and the United States Exports: Evidence from Canada and Japan. Journal of Japanese and International Economies, vol. 19, pp. 51-71.

Chowdhury, A.R. (1993). Does Exchange Rate Volatility Depress Trade Flows? Evidence from Error Correction Models. The Review of Economics and Statistics, pp.700-706.

Cushman, D.O. (1988). US Bilateral Trade Flows and Exchange Risk during the Floating Period. Journal of International Economics, vol.24, no. 3-4, pp. 317-330.

Deardorff, A. (1980). "The General Validity of the Law of Comparative Advantage", Journal of Political Economy, E Jonathan and S. Kortum (ed). 2002. "Technology, Geography, and Trade", Econometrica, vol. 70, pp.1741-1779.

Doroodian, K. (1999). Does Exchange Rate Volatility Deter International Trade in Developing Countries? Journal of Asian Economics, vol. 10, no. 3, pp. 465-474.

Ekanayake, E.M. and Chatrna, D. (2010). The Effects of Exchange Rate Volatility on Sri Lankan Exports: An Empirical Investigation. Journal of International Business and Economy, vol. 11, no. 1, pp. 51-68.

Fountas, S. and Aristotelous, K. (2005). The Impact of the Exchange Rate Regime on Exports: Evidence from the European Monetary System. Journal of Economic Integration, pp.567-589.

Franke, G. (1991). Exchange Rate Volatility and International Trading Strategy. Journal of International Money and Finance, vol. 10, no. 2, pp. 292-307. 
Fry-McKibbin, R. and Nguyen, T. (2017). Does Diplomacy Impediments to Trade? The case of Australia, Australian National University.

Hall S., Hondroyiannis, G., Swamy, P.A.V.B., Tavlas, G. and Ulan, M. (2010). Exchange-rate Volatility and Export Performance: Do Emerging Market Economies Resemble Industrial Countries or other Developing Countries? Economic Modelling, vol. 27, no. 6, pp.1514-1521.

Hayakawa, K. and Kimura, F. (200). The Effect of Exchange Rate Volatility on International Trade in East Asia. Journal of the Japanese and International Economies, vol. 23, no. 4, pp. 395406.

Kalirajan, K. (2018). IDEC8010 Quantitative International economics, Lecture on 30 March 2018, Crawford School of Public Policy, the Australian National University.

Lerner, A.P. (1936). The Symmetry between Import and Export Taxes. Economica, vol. 3, no. 11, pp. 306-313.

Linnemann, H. (1966). An Econometric Study of International Trade Flows, North Holland, Amsterdam.

Milanovic, B. (2016). Global inequality: A New Approach for the Age of Globalization, Harvard University Press.

Mukherji, IN (2000). Indo-Sri Lankan Trade and Investment Linkages: with Special Reference to SAPTA and Free Trade Agreement. South Asia Economic Journal, vol. 1, no. 1, pp. 5377.

Paudel, R.C. and Burke, P.J. (2015). Exchange Rate Policy and Export Performance in a Landlocked Developing Country: The Case of Nepal. Journal of Asian Economics, vol. 38, pp.55-63.

Perera, M.S. (2008). Impact of the Indo-Sri Lanka Free Trade Agreement on the Sri Lankan Economy: A Computable General Equilibrium Analysis. South Asia Economic Journal, vol. 9, no. 1, pp.1-50.

Rahmatsyah, T., Rajaguru, G. and Siregar, R.Y. (2002). Exchange-rate Volatility, Trade and "Fixing for Life in Thailand. Japan and the World Economy, vol. 14, no. 4, pp.445-470. 
Sauer, C., and Bohara, A.K. (2001). Exchange Rate Volatility and Exports: Regional Differences between Developing and Industrialized Countries. Review of International Economics, vol. 9, no. 1, pp.133-152.

Tinbergen, J. (1962). Shaping the World Economy; Suggestions for an International Economic Policy.

Weliwita, A., Ekanayake, E.M. and Tsujii, H. (1999). Real Exchange Rate Volatility and Sri Lanka's Exports to the Developed Countries, 1978-96. Journal of Economic Development, vol. 24, pp. $147-65$.

Zhang, K.H. (2005). How does FDI Affect a Host Country's Export Performance? The Case of China. In International conference of WTO, China and the Asian Economies, pp. 25-26. 